\title{
PSYCHE.
}

\section{DESCRIPTIONS OF SOME NORTH AMERICAN CORDULINA.}

BY HERMANN AUGUST HAgEN, CAMBRIDGE, MASS.

\section{[With Plate $\mathrm{I}$.}

\section{Epitheca yamaskanensis.}

Aeschna yamaskanensis Provancher Natur. Canad. I875, v. 7, $238 ; 248$.

Epitheca yamaskanensis Prov. ibid. r877, v. 9, 86. - Selys, 2d Add. syn. Cordul., I878, I3, 20, г 2 .

Male. Olive brown; front and vertex brown, blackish pilose, strongly punctated; front excavated above; labrum yellow, labium pale; antennae blackish; vertex convex above, narrowed to tip, which is half as broad at the base, nearly straight, a little impressed; occupit yellow, brown on tip, whitish pilose behind; yellow behind the eyes, two transversal brownish marks in the middle. Thorax olive brown, densely brownish pilose; dorsum dark brown, paler olive at the humeral suture and below the blackish brown sinus; carina obscure yellowish; sides olive brown; a yellow spot around the stigma ; below pale brown. Abdomen long, slender, inflated at the base, contracted on third segment, gradually broader to tip; third segment paler at base; segments 4-9 with a long yellowish spot on each side ; transverse sutures black ; articulation membrane yellowish; earlets moderate, dark brown, shining, round, pointed behind; last segment short, pale brown; a small dorsal carina not reaching the apical margin, which is prolonged into a triangular lobe between the superior appendages; base of the last segment notched; the articulation membrane enlarged. Superior appendages three times as long as the last segment, black, pilose, approximated, basal half cylindrical, about straight, somewhat contracted just after the base, apical half suddenly enlarged externally, a little divergent, the external border rounded, tapering to a short acute tip, recurved a little inwards and upwards; viewed from the sides, the basal half is cylindrical, a little incurvate, the apical half suddenly increased, tip recurved, acute; an obsolete external ridge not reaching the tip begins where the appendages enlarge and here on the underside is also a small notch. Inferior appendage a little shorter, light brown, triangular, large at base, very much narrowed and recurved on the apical half, ending in a blunt tip, somewhat thicker above. Genital parts on the second segment comparatively small; ventral lobe black, leaf shaped, margin thickened 
externally; hook pale yellowish, long, flat, larger at base, tapering to tip which is black, recurved, sharp; penis black, first joint with a short apical spine behind, second joint stout, short, with two erected spines on the tip; last joint cylindrical, pale; elevated spoon black, small, flat, incurved. Legs brown at base, femur blackish below, tibia black, the two margins above yellow; tarsi black; the legs are long, slender, pilose, with a small brush on the tip of the anterior femora; tip of the anterior tibia, with a short membrane below, ending with a spine projecting on the tip. Wings hyaline, somewhat smoky, veins black, costa externally yellow; pterostigma dull yellow, narrow, elongate, cut obliquely on tip; below $\mathrm{I} \frac{1}{2}$ areoles; the base of the wings orange to the arculus, except the apical half of the basilar space; the transversals in the median space and all below them are clouded with black, forming with the dull orange areoles on the hind wing a brownish looking basal spot; the three basal antecubitals in the subcostal space faintly clouded with orange; membranula long, snow-white, black at tip; the angle of the hind wing not sharp, less than rectangular; front wing with 9 antecubitals. 7 postcubitals; hind wing with 6 antecubitals, 7-8 postcubitals; triangle of front wings with 3 areoles, internal triangle empty ; triangle of hind wings with 2 areoles; two transversals in the median space; two series of discoidal areoles beginning with three; anal triangle of hind wings with I transversal ; basilar space of all wings empty.
Female. Similar to the male ; abdomen a little larger on tip; last segment pale, short, apical margin straight; appendages pale brown, blackish on tip, twice as long as the last segment, pilose, cylindrical, bent a little inside after the base, pointed on tip, vulvar lamina very short, with a large rectangular notch ; the lateral quadrangular lobes with the apical margin thickened; earlets wanting, a very small tubercule is visible, femur less dark than in the male; apical half of the anterior tibia with a series of pale flattened scales like spines; wings similar, front pair with II-10 antecubitals, 9 postcubitals; hind wings with 6 antecubitals, $10-9$ postcubitals; the internal triangle of the fore wings with 3 areoles.

Male Female

$\begin{array}{ccc}\text { Length of body with appendages } & 53 & 52 \\ \text { " " abdomen with " } & 40 & 40 \\ \text { " “ ala sup. } & 34 & 36 \\ \text { " " ala inf. } & 33 & 35 \\ \text { " “ pterostigma } & 2 \frac{1}{2} & 2 \frac{1}{2} \\ \text { " " appendages sup. } & 3 & 2 \frac{1}{2} \\ \text { " " tibia post. } & 7 & 7 \\ \text { Breadth of caput } & 7 \frac{1}{2} & 7 \frac{1}{2} \\ \text { "“ " ala sup. } & 8 \frac{1}{2} & 8 \frac{1}{2} \\ \text { " " ala inf. } & \text { I I } & \text { I I } \\ \text { Expanse of ala inf. } & 70 & 74\end{array}$

Habitat: Mt. Yamaska, near St. Hyacinth, Province of Quebec, Canada.

The male was collected by the Abbe Provancher in 1875 and the female in I 877. There can be no doubt that both belong to the same species; the difference of the internal triangle of the fore wings, empty and without transversals in the male, with three transversals, united in the centre and forming 3 areoles as in the discoidal triangle in the female is in- 
teresting, as in all the related species a lack of constancy in the venation is observed. This species is very similar to $E$. obsoleta, but the wings are narrower in proportion to the lingth. The other differences are given under $E$. obsoleta.

\section{Epitheca obsoleta.}

Libellula obsoleta Say Journ. acad. nat. sci. Philad. I839, ser. I, v. 8, 28, I7 : Ed Lec. v. 2, 402.

Didymops obsoleta Hagen Syn. Neur. N. A. 1861, 136, 2.

Epitheca? obsoleta Selys Syn. Cordul. 45, 25-Hagen Proc. Bost. soc. nat. hist., 1873, v. $15,269,24$.

Neurocordulia obsoleta Selys $2 \mathrm{~d}$. add. syn. Cordul., r878, 28.

Libellula polysticta Burm. Handb. 1839, v. $2,856,53$, o. ${ }^{1}$

Cordulia? molesta Walsh Proc. ent. soc. Philad. 1863 , v. 2, 254, 9 .

Male. Pale dull olive brown; front and vertex pale olive, brownish pilose,

${ }^{1}$ I have always used the names of the A. merican entomologist, Thomas Say, though I worked in Europe, and their priority over those of H. Burmeister is by no means certain. Say's paper was read 12 July, 1836 ; it was not published-I have never been able to learn why - until 1839. In my opinion the American entomologist can never lose priority by the unaccounted for delay in the publication of his paper.

Mr. Edward Doubleday (Mag. nat. hist., 1839, n. s. p. 14I) says : "This paper [of Say] was not published when I was in Cambridge, Mass., in October, [1838] but Dr. Harris informed me that it would appear in the forthcoming volume [v. 8] of the Journal of the academy of natural sciences, of Philadelphia. ... Epping, Feb. 18, 1839." strongly punctated, front excavated above; labrum yellow, labium paler; antennae pale brown; vertex convex above, narrowed to tip, which is half as broad as the base, nearly straight at the tip; occiput yellow, whitish pilose behind; behind the eves yellow, some brownish marks in the middle, but rather small. Thorax pale olive brown, densely brownish pilose ; dorsum with a darker broad dorsal stripe, shading off in the ground-color half way to the humeral suture; carina yellowish, sinus brown; a small yellow spot on each side of the dorsal stripe anteriorly near the prothorax ; sides with cuneiform yellow spots around the stigmata, reaching to the bases of the legs. Abdomen long inflated at the base, contracted on third segment, gradually enlarged to tip, and somewhat depressed (in bad condition); more yellowish along the lateral border; transverse sutures black; articulation membrane pale; a round yellow spot near the border of each side of the

Say's paper was therefore not published I 2 February, 1839 , as Doubleday prints (1. c.) a list of Say's entomological writings, by the kindness of Dr. Harris, more complete than any that has yet appeared.

The exact date of publication of the month$1 \mathrm{y}$ issues of the Journal from v. 2 to v. 6, p. 327 is given in the Proc. acad., v. 1 , p. 57-59, and concludes with the notice that "the remainder of the Journal is published in half volumes." Volume 8 has simply the date 1839. At that date Burmeister's work was certainly in print and was published direct$1 y$; but as I was in Norway and Sweden, I did not see it until the fall, when in A.ltona, at the house of Mr. Sommer, Burmeister's father-in-law. Priority hunters here and in Europe may do their work. 
second segment; earlet brown shining, round, pointed behind; last segment (base injured) with the apical margin slightly produced in the middle, rounded, very slightly depressed. Superior appendages a little more than twice as long as the last segment, pale brown, pilose, closely approximated in the apical half; basal half cylindrical, curved slowly inwardly and inferiorly; gradually enlarged externally on the apical half, and tapering to the tip, which is short acute, recurved inwardly ; viewed from the side the cylindrical basal half is somewhat contracted in front of the inflation of the apical half; inferior appendage a little shorter, pale brown, triangular, large at base, very much narrowed and recurved on the apical half, tip blunt with a small black tooth above. Genital parts wanting. Ventral lobe on the second segment small, brown, leaf-shaped, margins thicker, blackish. Legs pale brown, pilose, tibia externally yellowish, spines black; tarsi pale brown; anterior femora with a small brush on the tip; anterior tibiae with a short membrane below, ending in a spine projecting from the tip. Wings hyaline, broad, principally the hind wings, veins pale brown; pterostigma elongate, yellow, below little more than one areole ; the antecubitals in the subcostal space surrounded by a yellow spot, a similar spot near the arculus; transversals in the median space dark brown; hind wings with similar spots, and an orange one filling the triangle near the anal border; angle of the hind wings oblique nearly rounded; mem- branula long, snow-white, apical half blackish ; front wing with 7-8 antecubitals, 8 postcubitals; hind wing with 5 antecubitals, 7-9 postcubitals ; both triangles of front wings with 3 areoles ; discoidal triangle of hind wings with 2 areoles ; 2 transversals in the median space of all wings; one transversal in the basilar space of the left hind wing; discoidal areolets beginning with 3 , then 2 series for 2 areolets, followed by 3 not very regular series; anal triangle of hind wings with 2 transversals.

Female. Similar to the male; abdomen more robust, lateral margin of the segments paler; last segment very short, apical margin widely notched; appendages brown, black on tip, pilose, cylindrical, narrower at base, slightly bent outwards on tip, which is short, acute; tubercule between them brown, pilose, obtuse; vulvar lamina very short, with a large rectangular notch, almost attaining its base, sides rounded. Legs brown, tibiae yellowish externally, tarsi dark brown. Wings similar to the male, but slightly smoky, the costa yellow externally, all spots larger, a brownish spot on the base of the front wings near the hind border, and a larger brown band on the hind wings, ending on the interior angle of the discoidal triangle, leaving the extreme base of the wing hyaline; front wing with 7 antecubitals, and 7-8 postcubitals; hind wing with 5 antecubitals and 8 postcubitals; both triangles in front wings with 3 areoles; discoidal triangles in hind wings with two parallel transversals, of which in the right hind wing the basalone 
is furcated, giving 3 and 4 areoles ; median space of front wings with 2 (left) or 3 (right) transversals; median space of hind wings with 4 (left) or 3 (right) transversals; basilar space of all wings with I transversal; membranula snowwhite, blackish on tip.

Male Female

Length of body with appendages $43 \quad 45-53$

" " abdomen with " $30 \quad 34-36 \frac{1}{2}$

“ “ ala sup. $33^{\mathrm{I}} \quad 34-37 \frac{1}{2}$

“" " ala inf.

“ " " pterostigma

" " " appendages sup.

" " tibia post.

Breadth of head

" " ala sup.

“" " ala inf.

Expanse of ala inf.

Habitat : Indiana and Massachusetts, Say; New Orleans, La., Burmeister; Rock Island, Ill., Walsh; Galena, Ill., Mr. T. E. Bean. The types of Say from Indiana and the type of Walsh are destroyed. I saw the latter in 1868 and am sure that it belongs to E. obsoleta.

Say's type from Massachusetts, a female collected in 1820 in a meadow at Milton, near Boston, still exists in the Harris collection at the Boston society of natural history ; the type of Burmeister a male and a male from Galena are in my collection. These are the only specimens known and have been in the hands of Baron De Selys Longchamps for his Synopsis. The type of Burmeister is immature and in bad condition; it was placed in Didymops in my Synopsis as I did not care to found a new genus on such insufficient material and therefore placed the species in the genus I believed most suitable. I was aware that the branches of the tarsal nails were unequal, but the only specimen of $D$. transversa in my possession at that time was also in very poor condition, and the omission to state the difference in the claws induced Mr. Walsh to overlook the identity of his species with that of Say. This species is very close to E. yamaskanensis Provancher, of which I have seen the only pair known. Considering the aberrations in the vena. tion in E. obsoleta I believed after my first examination of the male, that both belong to the same species, but the discovery of the female seems to prove them different. E. yamaskanensis is larger, the head more globular, rather longer, occiput narrower, the wings longer but of the same breadth, the stigma shorter, the spots in the subcostal space almost wanting, antecubitals more numerous, the base of all the wings orange, legs longer, superior appendages of the male black, longer, visibly more dilated, with a small inferior notch in the middle; apical border between them prolonged into an acute recurved tip. I think it will be more prudent to accept them as distinct species until more specimens shall show intermediate forms.

3. Cordulia lintreri.

Cordulia lintneri Hagen $2 \mathrm{~d}$ Add. syn. Cordul. I 878,9 , $44 . *$

Male. Head large; labrum and labium bright yellow; face greenish

*This is Libellula vacua Hagen (no descr.) Stett. ent* zeit., 1867, v. 28, 91. The $\sigma^{*}$ is figured without name by Emmons, in DeKay Agric. N. Y., v. 5, pl. 15, f. I. 
rhinarium brownish in the middle; front advanced semicircular, somewhat flattened above, roughly punctated, slightly villous with pale hairs, front edge blunt; antennae blackish brown; between front and ocelli blackish; vertex short, transversal, rounded, roughly punctated with brown hairs; occiput yellow, rather pointed before; dilated posteriorly, rounded, impressed behind ; eyes large, blackish, brown behind, with long white hairs ; prothorax black, posterior lobe yellow, large elliptical ; thorax villous, transversally finely striated, shining; dark brown, sinus yellowish brown, the same color shaded down somewhat on each side before the sinus; part of the lateral sutures and some not well-defined spots near the legs black; beneath pale brown with large blackish spots behind the legs; abdomen short slightly villous, slender, cylindrical, the base enlarged; blackish brown, seg. ments I-9 with an apical yellow transversal band with the basis on the third segment, and is nearly separated in the middle of segments 8 and 9 ; segment Io as long as the $9^{\text {th }}$, convex above, with a basal median impression, black, shining; apical border straight slightly bent up; abdomen blackish beneath, the border of the segments somewhat paler in the middle, and on each side of segment three; second segment contracted in the middle, on each side with a large yellow earlet, rounded externally, pointed behind. Superior appendages a little longer than the last segment, separated at their basis, approached at their tips, straight cylindrical, the basal third flattened interiorly; after the first third externally below a small tooth and following to the tip inferiorly are six smaller ones; tip rounded with the appearance of a small soft point; inferior appendage a little shorter, triangular, strongly recurved, the point truncated; the appendages are black, hairy, the superiors pale brown on the tip, the inferior in the middle; genital lobe of the second segment triangular elongated; hooks long, bent, yellow, narrowed and brown on the tip; the spoon shaped elevator of penis enlarged on tip, yellow. ish. Legs black, moderately long, the hind ones passing the $3 \mathrm{~d}$ segment of abdomen; femora below rough, a large number of very short teeth; tibiae with black cilia; claws of tarsi unequal, the apical longer; femur of fore leg with a little brush on tip; tibiae of fore legs with the membranous plate; wings hyaline, a small yellow spot on the extreme base of all ; veins black, costa yellow; pterostigma yellow, small, the external side more oblique ; antecubitals 7 ; postcubitals $5-6$; all triangles without transversals; there is no inner triangle on the hind wing; one series of discoidal cells, the apical half beginning with two, later more; hind wings with the inner angle nearly rounded: anal triangle broad, with a transversal vein before the tip; membrane large, grayish white, ending on the transversal vein of the anal triangle.

Female. Similar to the male; the abdomen a little stouter, more enlarged at base, less retracted on the $3 \mathrm{~d}$ segment, no earlets, but the place a little 
inflated; colors similar but the transversal yellow bands larger and on the $3^{\mathrm{d}}$ and $4^{\text {th }}$ segments extended into a median dorsal line; last segment short, black, shining, with a flat basal impression; appendages as long as the segment, converging, cylindrical, rounded on tip, black, hairy ; part hetween them large, black rounded. Vulvar lamina large, broad, a little shorter than the segment, split to the basal third, pointed, tapering gradually to the tip, yellow; cavity bordered by it black, with an elevated ridge, pointed in iniddle.

Length
Abdomen
Ala sup.
Ala inf.
Pterostigma
Femur post.
Appendages

$\begin{array}{cc}\text { Male } & \text { Female } \\ 34 & 33 \\ 24 & 20-23 \\ 22 \frac{1}{2} & 23 \\ 22 & 2 \mathrm{I} \frac{1}{2}-22 \frac{1}{2} \\ 2 & - \\ 5 & 5 \\ 1 \frac{3}{4} & \mathrm{I}\end{array}$

Male Female

Exp. ala

Lat. cap.

Breadth ant.

" post.
48

$6 \quad 5^{\frac{1}{2}}$

6

7

Habitat : Center, N. Y.. Mr. J. A. Lintner, no. 2839, 27 May, $4 \delta^{\star}$; 2840, 2 I May, 49 . Two females (L. vacua Hagen, no descr.) from Saskatchewan, Lake Winnipeg, collected in 1860 by Robert Kennicott. The position of this rather eccentric, small species is near $C$. ulheri, but it is separated from that species by unusual characters. The anal angles of the hind wings of the male are nearly rounded; all triangles are without transversal veins: only one series of discoidal cells, and a very plain venation. It is very interesting that this apparently arctic species is found in eastern New York.

\section{DESCRIPTIONS OF SOME NEW NORTH AMERICAN DOLICHOPODIDAE.}

BY William M. WHEELER, MILWAUKEE, WiS.

(Concluded from. $p .3^{62}$.)

Peloropeodes, n. gen.

§. Small dull metallic green species. Palpi prominent, though not enlarged. Antennae as long as the head and thorax; first joint stout, subcylindrical, glabrous on its upper surface, with a few hairs on its under side; second joint short, rounded, subcalyculate; third joint pubescent, very long, tapering from a broad rounded base to a blunt point, on which is inserted the thick, flexible arista. Face rather broad for a male, front ample. Thoracic dorsum moderately arched, beset with the usual stout setae; scutellum broad, short, smooth, with four setae. Abdomen with six segments, short, stout at the base but tapering very rapidly to the apex, where is attached the sessile and greatly enlarged hypopygium, consisting of a scuttle shaped box, two thirds the size of the abdomen, from the ventrad directed opening of which protude several hook-shaped chitinous appendages. Legs rather stout. hairy; tibiae equalling the femora in length; spurs of the fore tibiae short, those of the posterior pairs 


\section{Explanation of Plate i.}

Epitheca yamaskanensis Provancher.

Fig. r. of Anal appendages, from above.

Fig. 2. $\delta$ Anal appendages, side view.

Fig. 3. $\$$ Anal appendages, from above.

Fig. 4. \& Anal appendages, side view.

Fig. 5. के Genitals in the second segment.

Fig. 6. $q$ Vulva, from below.

Epitheca obsoleta Say. (polysticta Burm.)

Fig. 7. $\delta$ Anal appendages, from above. (Burm.)

Fig. 8. of Anal appendages, side view. (Burm.)

Fig. 9. 9 Vulva, from below. (Say.)

Cordulia lintneri Hagen.

Fig. Io. $\delta$ Between anal appendages, from above.

Fig. I I. $\delta$ Anal appendages, from above.

Fig. I 2. $\delta$ Anal appendages, side view.

Fig. 13. $\delta$ Superior anal appendages, from above.

Fig. I4. \$ Anal appendages, from above.

Fig. I5. \& Vulva, from above.

Fig. I 5. - Head, from above.

Fig. 17. \& Base of wing.

All the figures are drawn from the types. 
Psyche, 1890.v.5.

Plate I
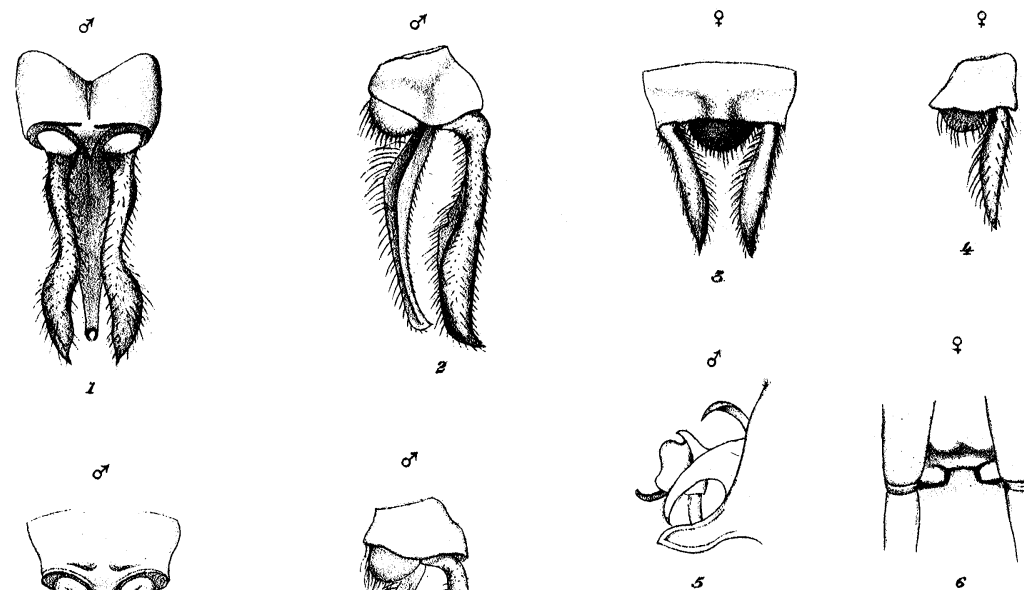

우
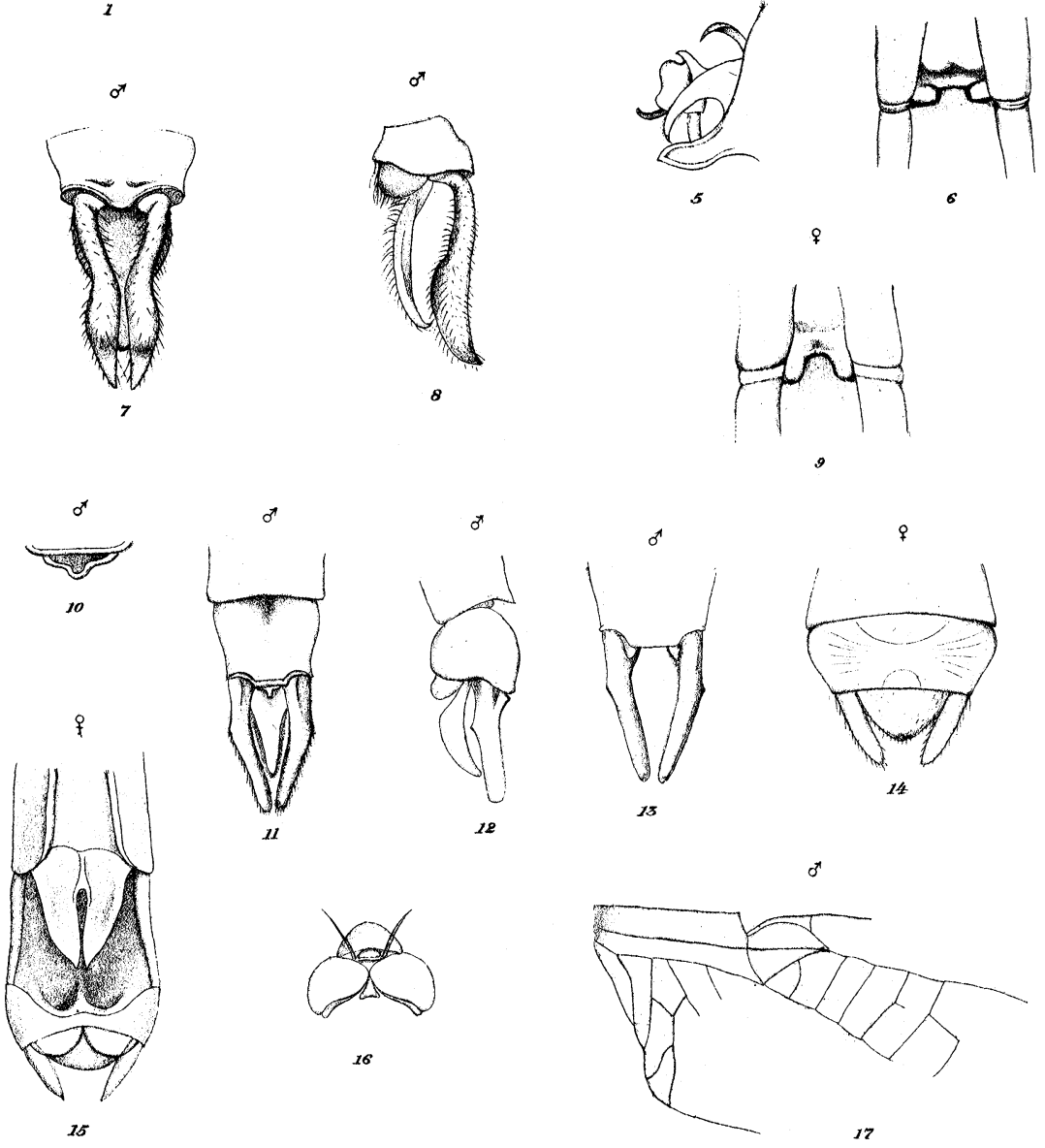

H.A.Hagen, del.

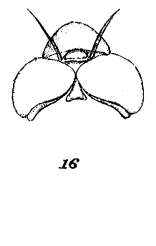

B.Meise\}, lith

HAGEN ON CORDULINA. 

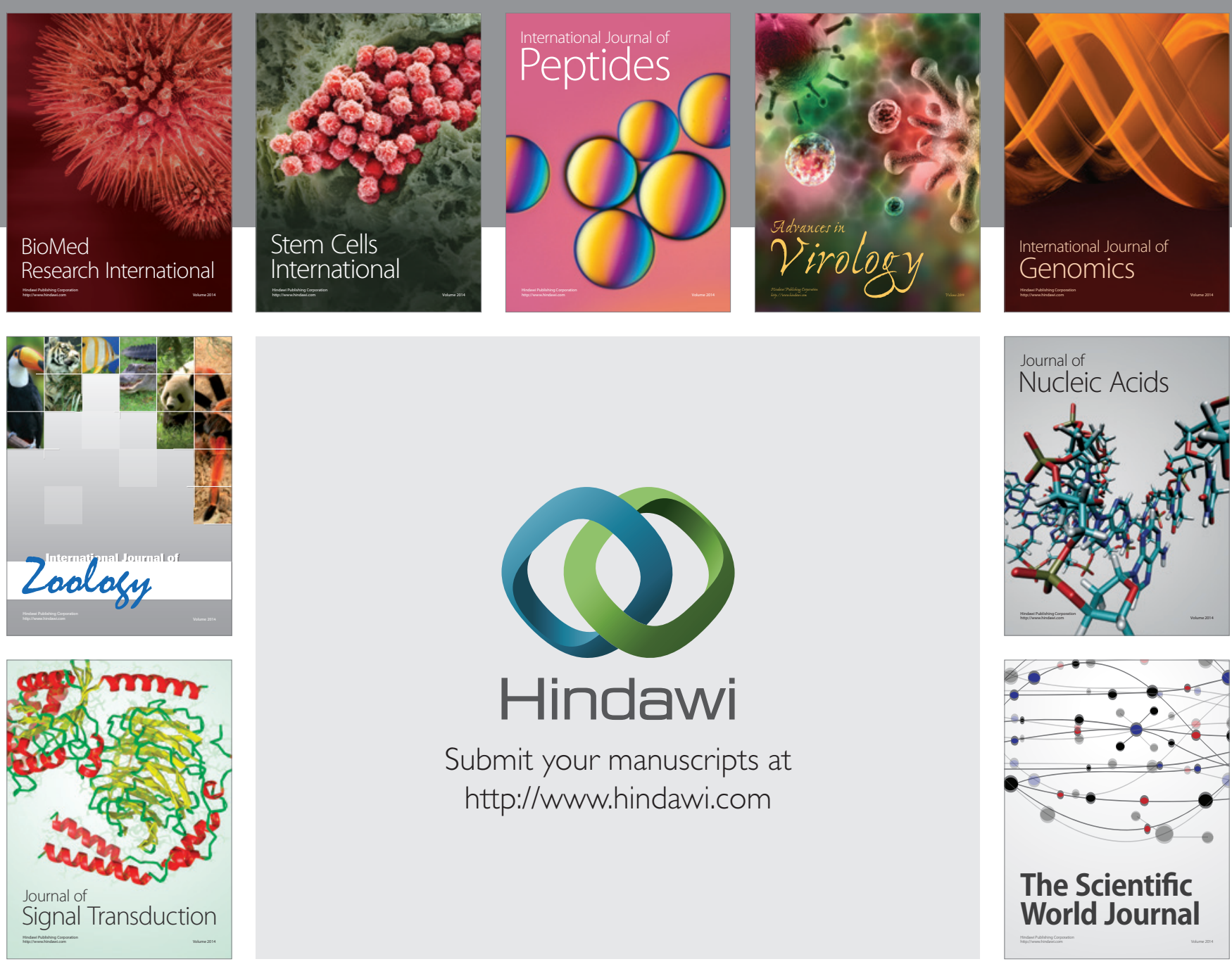

Submit your manuscripts at

http://www.hindawi.com
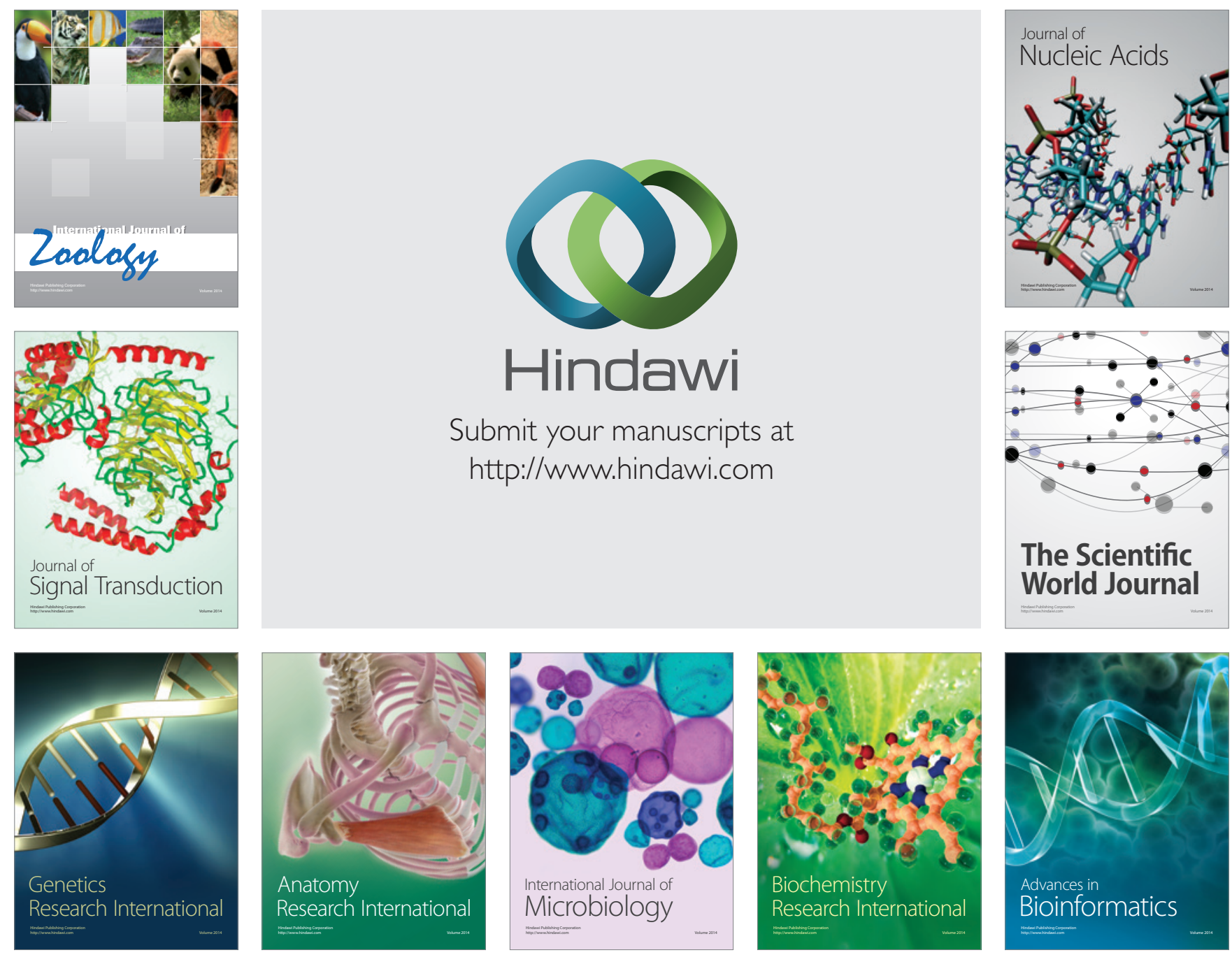

The Scientific World Journal
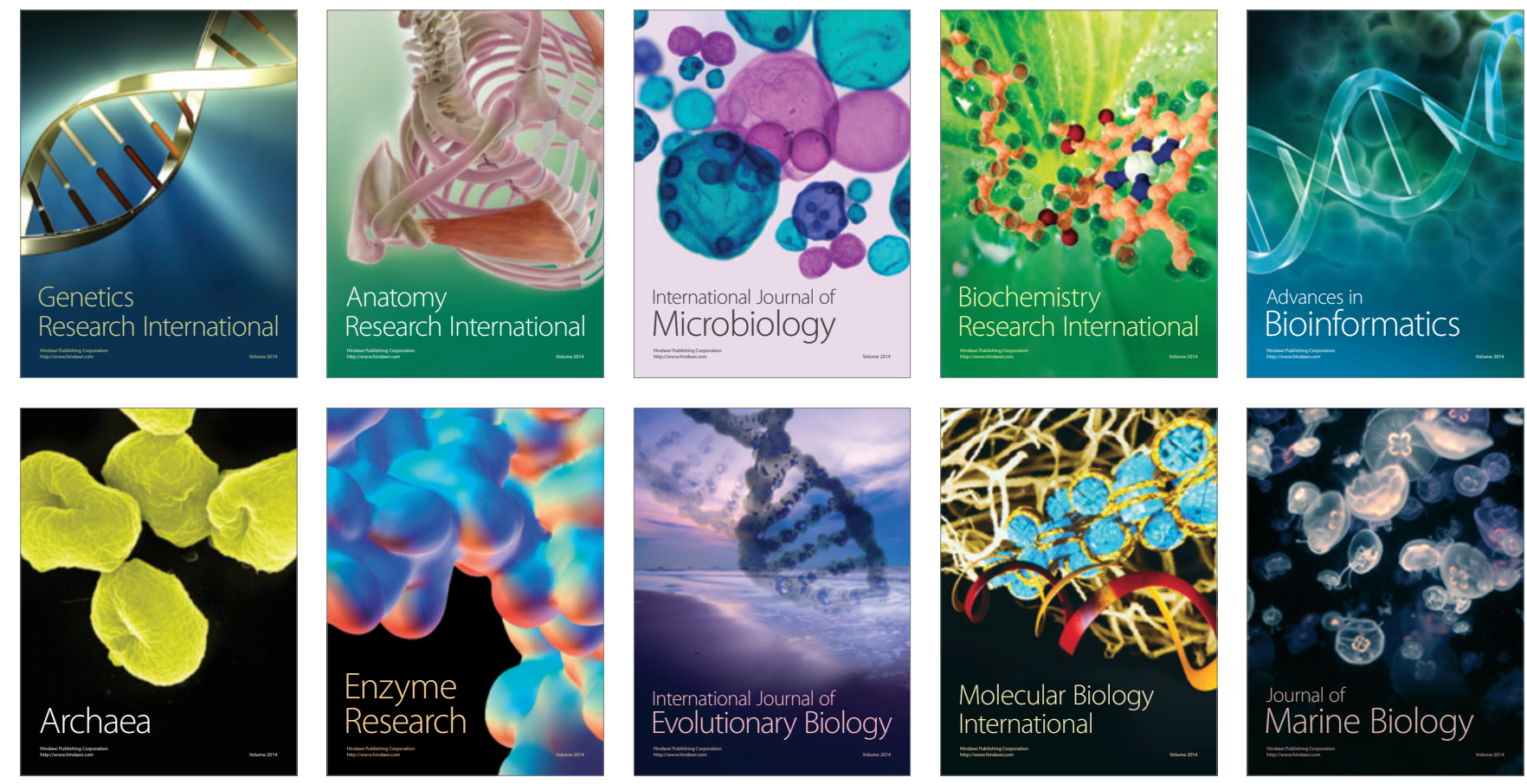